\title{
Excavated DNA from Two Khazar Burials
}

\author{
Anatole A. Klyosovi,2, Tatiana Faleeva ${ }^{3}$ \\ ${ }^{1}$ The Academy of DNA Genealogy, Boston, USA \\ ${ }^{2}$ The Academy of DNA Genealogy, Moscow, Russia \\ ${ }^{3}$ The National Forensic Center, Rostov-on-Don, Russia \\ Email: aklyosov@comcast.net
}

How to cite this paper: Klyosov, A. A., \& Faleeva, T. (2017). Excavated DNA from Two Khazar Burials. Advances in Anthropology, 7, 17-21.

https://doi.org/10.4236/aa.2017.71002

Received: December 19, 2016

Accepted: January 15, 2017

Published: January 18, 2017

Copyright (c) 2017 by authors and Scientific Research Publishing Inc. This work is licensed under the Creative Commons Attribution International License (CC BY 4.0).

http://creativecommons.org/licenses/by/4.0/ (c) (i) Open Access

\begin{abstract}
To understand a biological tribal affiliation (in terms of Y-chromosomal haplogroups, subclades, and haplotypes) of two excavated Khazar bone remains in the lower Don region in the south of Russia, we have extracted and analyzed their DNA and showed that both belonged to haplogroup R1a and its subclade Z93. The pattern could be considered typically "Turkic", and not a Jewish DNA lineage. Their haplotypes were also identified and reported here. The haplotypes indicate that both Khazars were unrelated to each other in a sense that their common ancestor lived as long as 1500 - 2500 years earlier than them, in the middle of the II millennium BC-beginning of the I millennium BC, during typically Scythian times or somewhat earlier. Their haplotypes are unrelated to well-known Jewish haplotypes of haplogroup R1a.
\end{abstract}

\section{Keywords}

Khazars, Haplogroups, Haplotypes, DNA Genealogy, TMRCA, Mutation Rates

\section{Introduction}

We report here what seems to be the first case of an ancient DNA study from Khazar burial mounds. Traditionally, Khazars are associated with ancient Jewish people; however, the extent of that association remains unknown. Overall, archeology of a few hundred Khazar burials dated from the VI through X centuries CE, assumed to be the timing for political history of Khazars, has not revealed any distinct indications to Jewish artifacts or anything related to ancient Jewish culture. It was certainly of interest to observe what the ancient Khazarian DNA would reveal in terms of haplogroups and haplotypes of Y-chromosome, which could be rather distinctly assigned to some tribal affiliations. 


\section{Results and Discussion}

Two human skeletons which were considered in this work, were obtained from two Khazar burial mounds in southern Russian steppes. The mounds, or kurgans, were typical Khazarian mounds surrounded by shallow square ritual ditches. Both burials are described in the literature (Ilyin, 1995; Parusimov, 1998; Glebov \& Ivanov, 2007; Batieva, 2007). Both burials, named Kuteiniki II (mound 2, burial 1) and Talov II (mound 2, burial 1), are located in the South-East of the Rostov region on the left bank of Don river, about 70 kilometers from each other. The first was excavated in 1994, the second in 2004. The first burial was robbed in the past. The human skeleton belonged to a male of $40+$ years old, the human bones were moved by the robbers, and the original burial position was uncertain. The burial was dated by the end of the VII to the beginning of the VIII century CE. The DNA sample obtained from the burial was assigned by the index 1251 .

The second burial was not robbed and was completely preserved. The human skeleton belonged to a male of 35 - 45 years old, positioned stretched on its back, the skull to the West. The burial was dated by the second half of the VIII to the beginning of the IX century CE. The DNA sample obtained from the burial was assigned by the index 1986 .

In the first half of the IX century kurgans with square ditches were seized to appear. The archaeological culture vanished. It seems that Khazars left the lower Don steppes during that time period; thus, Kuteiniki and Talovo burials mark early Khazar and late Khazar times, respectively, of their presence in the Don steppes.

The DNA in both cases was extracted from teeth of the ancient skeletons. The teeth were cleaned and ground in a vibration mill, the DNA was isolated by phenol extraction, and other routine procedures were employed for quantitation of the isolated DNA, such as the polymerase chain reaction. In both cases the Y-chromosomal haplogroup of the ancient Khazars was identified as R1a, and the primers specific to SNP mutations R1a-Z280 and R1a-Z93 revealed that the both samples showed negative Z280 and positive Z93 mutations. Thus, both ancient Khazars' DNA was interpreted to be of the R1a-Z93 "signature". This is a very rare SNP in present-day ethnic Russians, Ukrainians, Poles and other Slavic male populations, approximately $50 \%$ of whom are estimated to carry the R1a haplogroup (www.eupedia; Rozhanskii \& Klyosov, 2012). On the other hand, R1a-Z93 is very common in present-day Turkic-speaking peoples such as Caucasian Karachaevo-Balkars, also Tatars, Bashkirs, Kirgiz, and other populations who apparently descended from Scythians, and have their common ancestors in the R1a-Z93 subclade dated back to 1500 - 2500 years ago (Klyosov \& Rozhanskii, 2012; Klyosov \& Saidov, 2015).

In addition to their haplogroups and subclades, Y-chromosome haplotypes were determined in samples 1251 and 1986. In the 20 marker format (DYS 393, 390, 19, 391, 385a, 385b, 439, 389-1, 392, 389-2-DYS 458, 447, 437, 448, 449, GATA H4, 456, 576, 438, 635), their haplotypes were as follows: 
$1423 / 251611101410131133-15241420331115191123$ (1251)

$13251611111510131132-16241420321315181123$ (1986)

There are 9 - 11 mutations between these two haplotypes, which suggests a sizeable genetic distance between them. This distance translates into 9 $(11) / 0.0525=171$ (210) conditional generations (25 years each), corrected for back mutations (Klyosov \& Rozhanskii, 2012) equals 220 - 287 conditional generations or 5500 - 7175 years. The value of 0.0525 is the mutation rate constant for the 20 marker haplotypes (Klyosov \& Kilin, 2016). This figure divided by two gives the TMRCA (time to the most recent common ancestor) of 2750 3590 years. In other words, a common ancestor of the two Khazars lived in the middle of the II millennium BC-beginning of the I millennium BC, which has been associated with "classical Scythian times" (or even a little earlier). Clearly, these two haplotypes are not closely related to each other, they likely represent two different tribes, albeit both carried in the Y-chromosome the R1a-Z93 haplogroup. This is not surprising, since subclade R1a-Z93 formed approximately 5000 years ago (as determined by the analysis of their SNP-mutations, www.YFull). This haplogroup was discovered in the ancient timber-grave archaeological culture, as well as in the Potapov, Sintashta, Andronovo, Karasuk and other archaeological cultures (Haak et al., 2015; Allentoft et al., 2015); in the present day Indians, particularly in the Indian upper castes (Sharma et al, 2009), among Karachaevo-Balkars, Bashkirs, Tatars, Pashtuns, Tajiks, Uzbeks, Kirgiz, and many other peoples (Klyosov \& Saidov, 2015) with a high share of haplogroup R1a-Z93.

The identified haplotypes from the two Khazar burials cannot be assigned to Jewish haplotypes of the same R1a haplogroup (which are observed in about $10 \%$ Ashkenazim, www.eupedia), which in the same 20 marker haplotypes have the base (a common ancestral) haplotype as follows (Rozhanskii \& Klyosov, 2012; Klyosov \& Rozhanskii, 2012; Klyosov \& Saidov, 2015):

$13251610111410131130-14241420301114191123$

$13251610111410131130-14241420301114191123$

Mutations between the Jewish R1a ancestral haplotypes (dated about 1300 years before present; Rozhanskii \& Klyosov, 2012; Klyosov \& Rozhanskii, 2012; Klyosov \& Saidov, 2015) and those of samples 1251 and 1986, respectively (dated about 1200 years before present, see above), are marked in bold, and amounted to 11 - 13 and 12 mutations, respectively. Those mutation differences place the ancient Khazar R1a haplotypes and the ancestral Jewish R1a haplotype at a distance between them approximately equal to $12 / 0.0525=229 \rightarrow 323$ conditional generations, that is a distance of approximately 8075 years (here the arrow refers to a correction for back mutations) (Klyosov \& Rozhanskii, 2012). Taking into account that the Khazar R1a haplotypes are dated approximately 1200 years ago, and the ancestral Jewish R1a haplotype is dated about 1300 years ago, a common ancestor of the Khazar and Jewish haplotypes would have lived about $(8075+$ $1200+1300) / 2=5300$ years ago, if it was possible. However, it was hardly possible, because this "phantom" dating is thousands of years earlier compared to the 
appearance of Rla among the Jews (Rozhanskii \& Klyosov, 2012; Klyosov \& Rozhanskii, 2012; Klyosov \& Saidov, 2015).

\section{Conclusion}

The discovered subclades (R1a-Z93) and haplotypes from the two Khazar burials, one of early Khazar, and another of late Khazar times, are likely to be assigned to Turkic nomadic tribes, which migrated between Central Asia (and Altai region in particular) and the Black Sea area since the middle of the II millennium BC through the I millennium CE and some later. They belonged apparently to different tribes and different haplogroups (among them haplogroups $\mathrm{C}$, G, Q, R1a, R1b), however, thus far only haplogroup R1a was discovered among ancient excavated DNA of the Scythians and related tribes (Haak et al., 2015; Allentoft et al., 2015). This study describes ancient R1a haplogroup in two Khazar skeletons, dated about 1200 and 1300 years before present (earlier and later Khazars) though the two belonged to rather distant DNA lineages, with their common ancestor who lived some 1500 - 2000 years before them. Both the Khazars (R1a-Z93) were unrelated to ancestors of the present day ethnic Russians, Ukrainians, Belarus, Poles, and other Slavic peoples of haplogroup R1a (predominant subclades are R1a-Z280 and R1a-M458; Rozhanskii \& Klyosov, 2012), as well as Scandinavians of haplogroup R1a (the predominant subclade being R1a-Z284; ibid.). There are, however, many peoples with a rather large share of R1a-Z93, who speak Turkic languages, and who seem rather closely related to the DNA lineages of the excavated Khazars (some of them live in the Caucasus, some on the former Scythian and Khazar land, and in the area of Volga river, such as Tatars and Bashkirs. It should be noted that according to DNA genealogy data none of the two ancient Khazars belonged to the Jewish YDNA (Y-chromosomal DNA) lineage.

\section{Acknowledgements}

We thank V. Klyutchnikov (archaeologist) and I. Kornienko (forensic scientist) for valuable comments and discussion, and S. Hedeen for improving the manuscript.

\section{References}

Allentoft, M. E., Sikora, M., Sjogren, K.-G., Rasmussen, M., Stenderup, J., Damgaard, P. B., Schroeder, H. et al. (2015). Population Genomics of Bronze Age Eurasia. Nature, 522, 167-174. https://doi.org/10.1038/nature14507

Batieva, E. F. (2007). Anthropology of the Talov II Burial of the Khazar Times. In Ancient Artifacts from the Middle Age Don. Moscow: Jerusalem.

Glebov, V. P., \& Ivanov, A. A. (2007). A Nomad Burial of the Khazar Times from the Talov II Burial. In Ancient Artifacts from the Middle Age Don. Moscow: Jerusalem.

Haak, W., Lazaridis, I., Patterson, N., Rohland, N., Mallick, S., Llamas, B., Brandt, G. et al. (2015). Massive Migration from the Steppe Was a Source for Indo-European Languages in Europe. Nature, 522, 207-213. https://doi.org/10.1038/nature14317

Ilyin, A. S. (1995). Preliminary Observations of Pathological Changes in Human Bone 
Remains from Kuteiniki Kurgan 2, a Burial of Khazar Times. In Archaeological Cultures of Eurasian Steppes of the Second Half of the I Millennium CE. Abstracts of the Conference, Samara.

Klyosov, A. A., \& Kilin, V. V. (2016). Kilin-Klyosov TMRCA Calculator for Time Spans up to Millions of Years. Advances in Anthropology, 6, 51-71. https://doi.org/10.4236/aa.2016.63007

Klyosov, A. A., \& Rozhanskii, I. L. (2012). Haplogroup R1a as the Proto Indo-Europeans and the Legendary Aryans as Witnessed by the DNA of Their Current Descendants. Advances in Anthropology, 2, 1-13. https://doi.org/10.4236/aa.2012.21001

Klyosov, A. A., \& Saidov, Kh. S. (2015). The Jews and Pashtuns of Afghanistan. Conceptual Publishing House, Moscow, 460 p (in Russian).

Parusimov, I. N. (1998). Excavations of Kurgans in Zimovniki Region. Proceedings of the Novocherkassk Archaeological Expedition. Publ. 3, Novocherkassk.

Rozhanskii, I. L., \& Klyosov, A. A. (2012). Haplogroup R1a, Its Subclades and Branches in Europe during the Last 9000 Years. Advances in Anthropology, 2, 139-156.

https://doi.org/10.4236/aa.2012.23017

Sharma, S., Rai, E., Sharma, P., Jena, M., Singh, S., Darvishi, K., Bhat, A. K. et al. (2009). The Indian Origin of Paternal Haplogroup R1a1* Substantiates the Autochthonous Origin of Brahmins and the Caste System. Journal of Human Genetics, 54, 47-55. https://doi.org/10.1038/jhg.2008.2

http://www.eupedia.com/europe/european_y-dna_haplogroups.shtml

$\underline{\text { https://www.yfull.com/tree/R1a }}$

\section{Submit or recommend next manuscript to SCIRP and we will provide best service for you:}

Accepting pre-submission inquiries through Email, Facebook, LinkedIn, Twitter, etc. A wide selection of journals (inclusive of 9 subjects, more than 200 journals)

Providing 24-hour high-quality service

User-friendly online submission system

Fair and swift peer-review system

Efficient typesetting and proofreading procedure

Display of the result of downloads and visits, as well as the number of cited articles

Maximum dissemination of your research work

Submit your manuscript at: http://papersubmission.scirp.org/

Or contact aa@scirp.org 